\title{
The phylogenetic distribution of ultraviolet sensitivity in birds
}

\author{
Anders Ödeen ${ }^{1 *}$ and Olle Håstad ${ }^{2}$
}

\begin{abstract}
Background: Colour vision in birds can be categorized into two classes, the ultraviolet (UVS) and violet sensitive (VS). Their phylogenetic distributions have traditionally been regarded as highly conserved. However, the complicated nature of acquiring spectral sensitivities from cone photoreceptors meant that until recently, only a few species had actually been studied. Whether birds are UVS or VS can nowadays be inferred from a wide range of species via genomic sequencing of the UV/violet SWS1 cone opsin gene.

Results: We present genomic sequencing results of the SWS1 gene from 21 avian orders. Amino acid residues signifying UV sensitivity are found in the two most important spectral tuning sites 86 and 90 of Pteroclidiformes and Coraciiformes, in addition to the major clades, Palaeognathae, Charadriiformes, Trogoniformes, Psittaciformes and Passeriformes, where they where previously known to occur. We confirm that the presumed UVS-conferring amino acid combination F86, C90 and M93 is common to Palaeognathae and unique to this clade, despite available spectrometric evidence showing the ostrich retina to be VS.
\end{abstract}

Conclusions: By mapping our results together with data from previous studies on a molecular phylogeny we show that avian colour vision shifted between VS and UVS at least 14 times. Single nucleotide substitutions can explain all these shifts. The common ancestor of birds most likely had a VS phenotype. However, the ancestral state of the avian SWS1 opsin's spectral tuning sites cannot be resolved, since the Palaeognathae are F86, C90 while the Neognathae are ancestrally S86, S90. The phylogenetic distribution of UVS and VS colour vision in birds is so complex that inferences of spectral sensitivities from closely related taxa should be used with caution.

\section{Background}

Vision has played a major role in the evolution of animals. The need to accurately assess the quality of potential mates, spot elusive prey and detect luring predators have driven ecological adaptations in the eyes of vertebrates. The vertebrate eye reflects variation in its environment through the action of pigments in cone and rod photoreceptors with different absorption spectra, which are determined by their respective wavelength of maximum absorption $\left(\lambda_{\max }\right)$. The visual pigments consist of an opsin protein bound via a Schiff base to a chromophore, either 11-cis-retinal or 11-cis-3,4-dehydroretinal. Spectral tuning in all but one class of pigment is achieved by replacement of one of the chromophores for the other [1] (11-cis-retinal blueshifts compared to 11-cis-3,4-dehydroretinal [2,3]),

\footnotetext{
* Correspondence: anders.odeen@ebc.uu.se

${ }^{1}$ Department of Animal Ecology, Uppsala University, Norbyvägen 18D,

Uppsala S-752 36, Sweden Full list of author information is available at the end of the article
}

long-pass filtering by pigmented cone oil-droplets [4] or substitutions of key amino acids (aa) in the opsin protein (see refs. in [5]; reviewed by [6]). In the short-wavelength sensitive type 1 pigment (SWS1), $\lambda_{\max }$ is shifted from UVA to violet solely by aa replacements in the pigment opsin, since there is no long-pass filtering by the T-type cone oil droplet in the SWS1 cone [7-9]. Apparently no more is required than a single base substitution, displacing the $\lambda_{\max }$ by $31-47 \mathrm{~nm}[5,10,11]$.

In recent years, portable spectrophotometers and the development of vision physiological models have made it possible to quantify how colour signals are perceived by the natural observer, a bird for example, given that visual physiological data for the species in question are known. Since in-depth physiological studies on the visual system have been limited to a few species, researchers have had to rely on a widely accepted assumption of strong phylogenetic inertia in the evolution of colour vision systems,
Ciomed Central 
using data from related species, in which the information is available [12].

Diurnal birds, which are highly dependent on colour vision, have evolved two distinct classes of colour vision, the violet sensitive (VS) and the ultraviolet sensitive (UVS) [13]. The foremost difference is that the most shortwave sensitive cone, the SWS1 (UV/violet), has a longwave shifted wavelength of maximum absorption $\left(\lambda_{\max }\right)$ in the VS class (402-426 nm) compared to the UVS (355-380 $\mathrm{nm})$ (reviewed by [14,15] (Figure 1). The "blue" sensitive SWS2 cones $\left(\lambda_{\max } 451-480 \mathrm{~nm}\right)$ are also longwave shifted in VS birds but to a lesser degree (see review in [14]). Furthermore, the lens and cornea usually show distinctly stronger UV absorption in VS than in UVS species (reviewed in $[16,17])$. It is important to ecologists to be able to distinguish the two classes of colour vision. Birds use UV cues in both mate choice [18-28] and foraging [29-34]. The UVS class makes the animal more able to discriminate between colours in the natural surroundings (see $[35,36])$ compared to the VS. For example, parents with UVS vision appear to be better at discriminating colour signals of nestlings [37]. Furthermore, as $\lambda_{\max }$ values differ considerably from those of the VS class, UVS colour vision can grant birds some degree of privacy from VS predators in visual intraspecific communication [38].

Ten years ago it appeared that birds, in contrast to vertebrates as a whole, were ancestrally violet sensitive and that UV sensitivity reappeared once in a common ancestor of passerines and psittaciforms (parrots and allies) [6]. This conclusion was however drawn from less than a dozen bird species that had been investigated through retinal microspectrophotometry (MSP) or in vitro regeneration and spectrophotometry of photopigments (see reviews in $[14,15]$ ).

Genomic sequencing of small DNA samples has since offered a feasible alternative to gain further insights into the spectral sensitivities of birds. This method is potentially non-destructive and considerably faster to use, compared to MSP and in vitro pigment regeneration. The targets are non-conservative substitutions (i.e. involving change of charge or loss or gain of a hydroxyl group) that are located in the retinal binding pocket of the opsin protein, on the inner side of its alpha-helices, close enough to directly interact with the Schiff base linkage to the retinal chromophore (e.g. [40]). In the year 2000, two studies, Wilkie et al. [5] and Yokoyama et al. [10], introduced these mutations into the sequence of isolated SWS1 opsin gene from budgerigar Melopsittacus undulatus and zebra finch Taeniopygia guttata. They showed that replacement of cysteine by serine in the $90^{\text {th }}$ aa position, the substitution C90S, alone accounts for the whole shift in $\lambda_{\max }$ from UVS to VS (all aa numbering in this article corresponds to the bovine rhodopsin [41]). Furthermore, reverse mutations in chicken Gallus gallus and pigeon Columba livia by Yokoyama et al. [10] produced the full shift from VS to UVS. With these findings at hand we [42] designed primers to PCR amplify fragments from genomic DNA that spanned the proposed major tuning site. From 45 species distributed across 14 bird orders we could confirm in 2003 that ancestral birds likely carried S90 and were hence VS but also that ultraviolet vision had been regained by the S90C substitution not once but four times independently. Ödeen et al. [15] later validated the accuracy of this method in distinguishing UVS from VS species against published MSP data.

The genomic DNA sequences revealed novel combinations of aa residues; although S90 is paired with S86 in all species determined by MSP to be VS, it is combined with A86, I86, C86 or F86 in some other species [42]. These findings lead Carvalho et al. [11] to test alternative substitutions in sites 86 and 90 to UV-shift a pigment in vitro, successfully shifting VS pigeon and chicken pigments into the ultraviolet with S86F. Similar to $\mathrm{S} 90 \mathrm{C}, \mathrm{S} 86 \mathrm{~F}$ is a shift from a polar aa residue to a non-polar one in a suitable position to destabilize protonation of the Schiff base linkage between retinal and the opsin, leading to an unprotonated Schiff base,

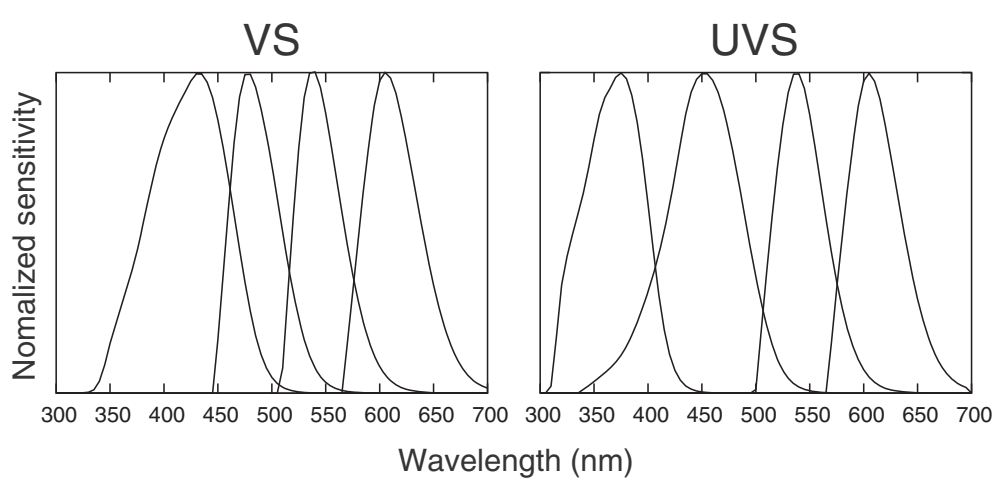

Figure 1 Examples of spectral sensitivities for VS and UVS birds. Normalized sensitivities for the single cone classes (from left to right) SWS1, SWS2, MWS and LWS, including the effects of ocular medium absorption. The VS example is the Indian peafowl Pavo cristatus [39] and the UVS is the Eurasian blue tit Cyanistes caeruleus [9]. Human visible range is approximately 400-700 nm; wavelengths below that range are termed ultraviolet. 
Table 1 Bird species sequenced for this study

\begin{tabular}{|c|c|c|c|c|c|c|c|c|}
\hline Order & Family & Species & Common name & aa seq $84-94$ & Type & Origin/voucher* & Tissue no* & Acc no \\
\hline Struthioniformes & Struthionidae & Struthio camelus & Common ostrich & FIFCVFCVFMV & VS & Strutsens café & Struts 2012 & HF565322 \\
\hline Casuariiformes & Casuariidae & Casuarius casuarius & Southern cassowary & FIFCVLCVFMV & US & & EBU 46990 & HF565323 \\
\hline Casuariiformes & Dromaiidae & Dromaius novaehollandiae 2 & Emu & FIFCVLCVFMV & VS & O. $70526,0.71207 .001$ & EBU 11410, EBU 45181 & HF565324, HF565325 \\
\hline Galliformes & Phasianidae & Lagopus muta & Rock ptarmigan & FISCILSVFVV & VS & T Sahlman, UU & 39 & HF565326, HF565327 \\
\hline Galliformes & Phasianidae & Lagopus lagopus & Willow ptarmigan & FISCILSVFVV & VS & J Höglund, UU & JHGO009 & HF565328 \\
\hline Anseriformes & Anatidae & Branta bernicla & Brant goose & FISCIFSVFIV & VS & SVA & $682 / 01$ & HF565329 \\
\hline Anseriformes & Anatidae & Cairina moschata & Muscovy duck & FVSCXFSVFIV & VS & Uppsala kommun & Mysk & HF565330 \\
\hline Anseriformes & Anatidae & Mergus merganser & Goosander & FISCIFSVFIV & VS & $\mathrm{IBG}, \mathrm{UU}$ & Storskrake & HF565331 \\
\hline Procellariiformes & Procellariidae & Pterodroma macroptera 2 & Great-winged petrel & FISCIFSVFTV & VS & -, UWBM 80995 & -, CJRR 33466 & $-{ }^{\dagger}$, HF565332 \\
\hline Podicipediformes & Podicipedidae & Podiceps cristatus & Great crested grebe & FICCIFSVFTV & VS & SVA & $799 / 01$ & HF565333 \\
\hline Phaethontiformes & Phaethontidae & Phaethon rubricauda 3 & Red-tailed tropicbird & FMACIFSVFTV & VS &,- 0.71305 & -, EBU 45522 & $\begin{array}{l}\text { HM212420 } \\
\text { HM212423 } \\
\text { HF565334, }\end{array}$ \\
\hline Phaethontiformes & Phaethontidae & Phaethon lepturus fulvus & White-tailed tropicbird & FMACIFSVFTV & VS & O. 71298 & EBU 45518 & HF565335 \\
\hline Pelecaniformes & Threskiornithidae & Plegadis falcinellus & Glossy ibis & FISCIFSVFTV & VS & NRM 20026066 & & HF565336 \\
\hline Pelecaniformes & Threskiornithidae & Platalea ajaja & Roseate spoonbill & FISCIFSVFTV & VS & NRM 976748 & AHN-354 & HF565337 \\
\hline Accipitriformes & Cathartidae & Cathartes aura ruficollis & Turkey vulture & FISCIFSVFTV & VS & NRM 956726 & & HF565338 \\
\hline Accipitriformes & Accipitridae & Aviceda subcristata & Pacific baza & FICCIFSVFIV & VS & UWBM 76618 & EVL 511 & HF565339 \\
\hline Accipitriformes & Accipitridae & Ictinia mississippiensis & Mississippi kite & FICCIFSVFTV & VS & UWBM 80091 & EVL 706 & HF565340 \\
\hline Mesitornithiformes & Mesitornithidae & Mesitornis unicolor & Brown mesite & FLCCIFSVFTV & VS & FMNH 346010 & & HF565341 \\
\hline Eurypygiformes & Rhynochetidae & Rhynochetos jubatus & Kagu & FISCVFSVFTV & VS & 0.71868 .001 & & HF565342 \\
\hline Eurypygiformes & Eurypygidae & Eurypygia helias & Sunbittern & FISCIFSVFTV & VS & LSUMZ B38508 & & HF565343 \\
\hline Charadriiformes & Scolopacidae & Actitis macularius & Spotted sandpiper & FIACIFSVFTV & VS & J Höglund, UU & $\mathrm{JHGOX157}$ & AY960714** \\
\hline Pteroclidiformes & Pteroclididae & Syrrhaptes paradoxus 2 & Pallas's sandgrouse & FIFCTFSVFTV & UVS & $\begin{array}{l}\text { UWBM 59840, UWBM } \\
59842\end{array}$ & CSW 5807 & HF565344, HF565345 \\
\hline Pteroclidiformes & Pteroclididae & Pterocles bicinctus & Double-banded sandgrouse & FIFCSFSVFTV & UVS & UWBM 53231 & SVD 896 & HF565346 \\
\hline Columbiformes & Columbidae & Ptilinopus magnificus & Wompoo fruit dove & FISCIFSVFTV & VS & 0.73263 .001 & & HF565347 \\
\hline Psittaciformes & Cacatuidae & Cacatua alba & White cockatoo & FLACIFCIFTV & UVS & Djurkliniken Roslagstull & & HF565348 \\
\hline Psittaciformes & Cacatuidae & Nymphicus hollandicus & Cockatiel & FLACIFCIFTV & UVS & Fyris Zoo & & HF565349 \\
\hline Psittaciformes & Psittacidae & Aratinga aurea & Peach-fronted parakeet & FLACIFCIFTV & UVS & NRM 976646 & AHN-308 & HF565350 \\
\hline Psittaciformes & Psittacidae & Pyrrhura frontalis & Maroon-bellied parakeet & FLACIFCIFTV & UVS & NRM 966979 & GFK-257 & HF565351 \\
\hline Psittaciformes & Psittacidae & Forpus xanthopterygius & Blue-winged parrotlet & FLACIFCIFTV & UVS & NRM 986799 & LAA-094 & HF565352 \\
\hline Opisthocomiformes & Opisthocomidae & Opisthocomus hoazin & Hoatzin & FICCIFSVFTV & VS & LSUMZ B-10753 & & HF565353 \\
\hline Musophagiformes & Musophagidae & Tauraco porphyreolophus & Purple-crested turaco & FISCIFSVFTV & VS & UWBM 52953 & SAR 6784 & HF565354 \\
\hline
\end{tabular}


Table 1 Bird species sequenced for this study (Continued)

\begin{tabular}{|c|c|c|c|c|c|c|c|c|}
\hline Trogoniformes & Trogonidae & Harpactes erythrocephalus & Red-headed trogon & FIFCVFSVFTV & UVS & NRM 20026658 & VNM2002-049 & HF565355 \\
\hline Coraciiformes & Momotidae & Momotus momota & Amazonian motmot & FIFCSFSVFTV & UVS & NRM 947281 & ICM-078 & HF565356 \\
\hline Coraciiformes & Momotidae & Baryphthengus ruficapillus & Rufous-capped motmot & FIFCSFSVFTV & UVS & NRM 937319 & & HF565357 \\
\hline Coraciiformes & Momotidae & Eumomota superciliosa & Turquoise-browed motmot & FIFCSFSVFTV & UVS & NRM 20066359 & & HF565358 \\
\hline Coraciiformes & Meropidae & Merops apiaster & European bee-eater & FVSCIFSVFTV & VS & S Berlin, UU & $1 / 1$ & HF565359 \\
\hline Piciformes & Megalaimidae & Megalaima virens & Great barbet & FISCIFSVFTV & VS & R den Tex, UU & $x-2009$ & HF565360 \\
\hline Piciformes & Ramphastidae & Ramphastos tucanus & White-throated toucan & FISCIFSVFTV & VS & $\mathrm{IBG}, \mathrm{UU}$ & Tukan & HF565361 \\
\hline Piciformes & Picidae & Picus viridis & $\begin{array}{l}\text { European green } \\
\text { woodpecker }\end{array}$ & FLSCIFSVFTV & VS & $\mathrm{AÖ}$ & Sko01 & HF565362 \\
\hline Passeriformes & Pipridae & Manacus manacus 2 & White-bearded manakin & FMCCIFSVFTV & VS & $\begin{array}{l}\text { L Shorey, Dept } \\
\text { Population Biology, UU }\end{array}$ & LS015, LS241 & $\begin{array}{l}\text { HF565363, } \\
\text { AY227182*** }\end{array}$ \\
\hline
\end{tabular}

Notes: *Australian Museum (O., EBU), Australian National Wildlife Collection (ANWC), Biology Education Centre, Uppsala university (IBG), Field Museum of Natural History, Chicago (FMNH), Louisiana State University Museum of Natural Science, Baton Rouge (LSUMZ), National Veterinary Institute of Sweden (SVA), Swedish Museum of Natural History (NRM), University of Washington, Burke Museum (UWBM), Uppsala University (UU). ${ }^{\dagger}[45],{ }^{*}[46],{ }^{* *}$ species misidentified in [47], ${ }^{* * *}$ re-analysed sample from [42].

The type of SWS1 single cones (VS or UVS) is interpreted from opsin amino acid (aa) identities. The paleognathous Struthioniformes and Casuariformes are assumed to be VS based on MSP data from ostrich Strutio camelus [48] and aa sequence similarity. Bold letters mark spectral tuning amino acid positions 86,90 and 93 . Number of birds sequenced is indicated after species names. 


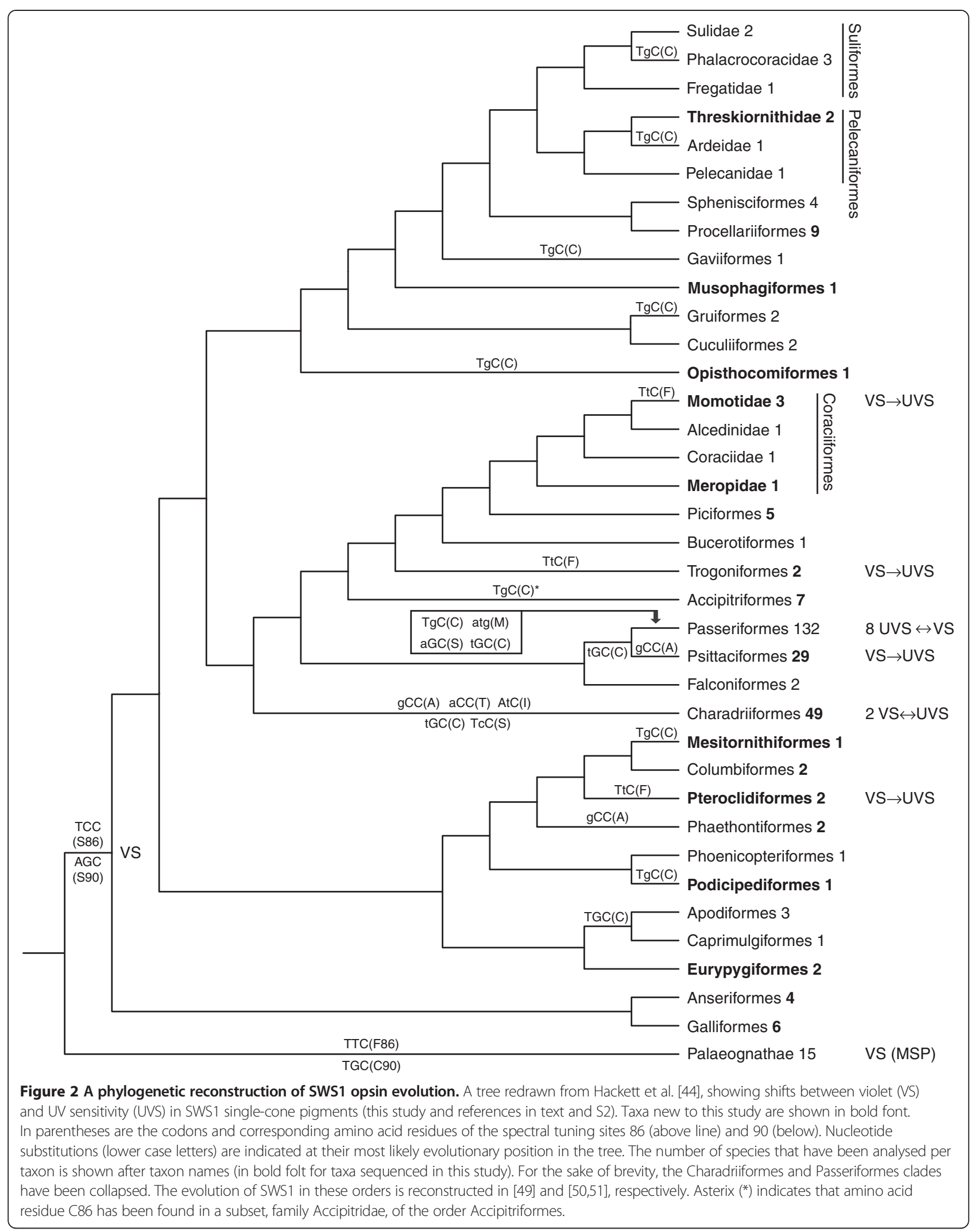


which is typical of UVS pigments [11]. The authors hence implied that the naturally F86, S90 blue-crowned trogon Trogon curucui is UVS.

Conferred by the presence of either F86 or C90 aa residues, ultraviolet sensitivity (i.e. UVS type opsin genes) may prove to be much more common than previously predicted if the avian SWS1 opsin were sequenced from a denser phylogenetic sample. For this study we have applied genomic sequencing to determine VS or UVS affiliation in species that belong to a number of higher taxa with unknown spectral sensitivities. By compiling the results with published data and mapping these onto a recent phylogeny we trace the evolution of ultraviolet sensitivity in birds.

\section{Results}

Cycle sequencing produced 50-160 bp long overlapping sequences of the SWS1 opsin gene from 40 species belonging to 29 families and 21 orders (taxonomy according to the IOC World Bird List [43]), 11 families and six orders being new to this study. We failed to amplify the SWS1 opsin gene in the palaeognath southern brown kiwi Apteryx australis. Amino acid translations showing the spectral tuning sites 86, 90 and 93 [5] are presented in Table 1. The phylogenetic distribution of the major tuning aa residues located in sites 86 and 90 are shown in a tree (Figure 2) that is based on the molecular phylogeny of Hackett et al. [44].

We found residues of C90 in the Palaeognathae species ostrich Strutio camelus, southern cassowary Casuarius casuarius and emu Dromaius novaehollandiae (confirming [52]), as well as in the two Cacatuidae and three Psittacidae species, confirming that $\mathrm{C} 90$ is common to Psittaciformes (New Zealand parrots, cockatoos and true parrots) (cf. $[40,42,52,53])$. F86 was found present in the Trogoniformes red-headed trogon Harpactes erythrocephalus, all three Momotidae species sampled, rufous-capped motmot Baryphthengus ruficapillus, turquoise-browed motmot Eumomota superciliosa and blue-crowned motmot Momotus momota, and both Pteroclidiformes species sampled, Pallas's sandgrouse Syrrhaptes paradoxus and double-banded sandgrouse Pterocles bicinctus, as well as confirmed in the ostrich, southern cassowary and emu (cf. [52], Additional file 1). The combinations A86, C86 or S86 with S90 were common to all the other specimens. Site 93 held threonine in most specimens, isoleucine in some, but methionine in all paleognaths (as in all paleognaths [42,52]).

All Palaeognathae are F86 and C90, coded by TTC and TGC, while serine in both site 86 and the 90 , coded by TCC and AGC respectively, is the most parsimonious ancestral state for the Neognathae (the remaining taxa) (Figure 2). Single nucleotide substitutions from AGC to TGC appear to have occurred in the ancestors of C90 species and other single nucleotide substitutions have resulted in the aa substitutions S86F, S86C and S86A. All aa changes in sites 86 and 90 may be parsimoniously interpreted as non-conservative substitutions.

Our rock ptarmigan Lagopus muta sequences differ by three out of eleven aa residues from that published in Håstad et al. [47] (Table 1). Their sequence originated from the same sample as our spotted sandpiper Actitis macularius but was misidentified due to a case of mislabelling confirmed by the collection manager. The ostrich and white-bearded manakin Manacus manacus aa sequences reported here are similar to those recently published by Aidala et al. [52] but not compared to an earlier study (Ödeen and Håstad [42]). Through resequencing and mtDNA barcoding of the samples from [42] we have determined that the ostrich sample was misidentified at the source and the manakin during sequencing. Two aa residues in the manakin sequence in [42] are hereby corrected but the change (S86 to C86) is not likely relevant to spectral tuning (cf. [11]). The revision of the ostrich however changes what was believed to be a VS S86, S90 coding genotype into a supposedly UVS F86, C90, common to other paleognaths.

\section{Discussion}

With the results of this study, information has become available on the SWS1 opsin's VS-UVS state for most higher order avian taxa.

Avian evolution has seen at least 14 shifts between VS and UVS colour vision (this study and $[5,15,16,40,42,45-$ 47,49-60]). If Passeriformes and Psittaciformes are sister orders (Figure 2 [44]), UV vision has been regained eight or nine times. Serine in site 90 has been substituted by cysteine (S90C) five or six times, depending on the number of reverse substitutions (see below): in a charadriiform ancestor of Larus gulls and allies gulls, Anous and Gygis terns, and black skimmer Rynchops niger [49], in an ancestor of Psittaciformes (see [40,42,52,53]) and Passeriformes, and three or four times in Passeriformes [50,51]. Ultraviolet shifts by the substitution S86F, without S90C, seem to have taken place three times (Figure 2): in Pteroclidiformes, Trogoniformes (see also [42]) and Coraciiformes (Momotidae). It should be noted however that the in vitro shift resulting from S86F in chicken and pigeon pigments [11] remains to be confirmed in vivo by e.g. MSP in such a taxon where F86 occurs naturally. There is evidence of five or six reversals to VS by C90S in Aves, depending on the number of S90C: one in the Charadriiformes [49] and four (if four S90C) or five (if three S90C) in Passeriformes [50,51].

The ancestral aa residues cannot be reconstructed for the two most important spectral tuning sites of the avian SWS1 opsin. This study supports recent findings by Aidala et al. [52] that all paleognaths hold F86 and C90 but suggests by parsimony (Figure 2) that S86 plus S90 was present in the common ancestor of all other extant 
birds (Neognathae). However, the common ancestor of birds was most likely VS rather than UVS. The only paleognathous species that has been investigated by MSP, the ostrich, has VS SWS1 single cones [48]. By priority of direct evidence (MSP) over indirect (genomic sequencing) we conclude that Palaeognathae have VS photopigments, and thus that one or more unknown aa's in the SWS1 opsin stabilizes protonation of the Schiff base linkage to the retinal despite the presence of C90. A likely candidate is the nonpolar methionine that paleognaths share at site 93 (Additional file 1). Another nonpolar aa at site 93, proline, has recently been shown to be important to primate VS pigments [59]; the substitution P93T shifts the VS aye-aye Daubentonia madagascariensis pigment's $\lambda_{\max }$ into the UV. In addition to Palaeognathae, Laridae and Acanthisitta chloris have C90 together with nonpolar aa residues (I or L and L, respectively) at site 93, and might therefore have VS phenotypes due to similar stabilizing effects on Schiff base protonation. However, it is known from sitedirected mutagenesis [5] that the polar to nonpolar substitution T93V only has a very minor effect $(3 \mathrm{~nm})$ on spectral tuning of a C90 SWS1 opsin pigment. We are therefore reluctant to assume a general, strong effect of nonpolar aa's at site 93 in birds until it is supported by in vitro expression or MSP.

Point mutations can explain almost all aa substitutions at sites 86 and 90. The S90C induced UV shifts seem to have been caused by the codon AGC changing to TGC, while both AGC and TCC have been responsible for C90S reversals to violet (see [49-51]. Other single nucleotide substitutions have resulted in S86F, S86C and S86A. A parsimonious interpretation, consistent with the phylogenetic reconstruction of ultraviolet vision in Charadriiformes (shorebirds) by Ödeen et al. [49], is that point mutations also caused A86T in the ancestor of Sterna and allies terns, and then T86I in the ancestor of gulls. The only exception seems to be a triple nucleotide substitution from TCC to ATG (C86M) (see [51]) in a common ancestor of the Passerida, Sylvoidea passerine families (sensu Johansson et al. [61]) Pycnonotidae, Hirundidae, Phylloscopidae, Acrocephalidae, Donacobidae, Timaliidae and Zosteropidae.

Despite 14 shifts between violet and UV vision during avian evolution, the simple nature of the mechanism behind them makes one wonder why some clades are invariably VS or UVS; all that is required for a shift is apparently a point mutation [5,10,11]. With the exception of Malurus fairywrens [50], multi-sampled avian genera show no polymorphism in SWS1 $\lambda_{\max }$, but hold either VS or UVS type sequences (Additional file 1).

VS-UVS shifts in the SWS1 pigment may have to happen in correlation with other changes in the physiology of the eye to be positively selected. A shortwave shift in a VS
SWS1 pigment should not produce a significant increase in UV sensitivity unless it is preceded by an increased transmission of UV in the ocular media (a lowered cut-off wavelength $\left(\lambda_{\text {T0.5 }}\right)$ [16]. There may be a cost associated with increased UV transmission as shortwave radiation is absorbed by and photooxidizes biological tissue (e.g. $[53,62])$. The ocular media of most VS birds filter out some of the ultraviolet radiation, thereby limiting the photooxidative damage on the retina. Reduced visual acuity and contrast by chromatic aberration and Rayleigh scattering takes an additional toll on widening spectral transmission to shorter wavelengths [63]. Moreover, single-cone sensitivities would become unevenly distributed across the spectrum, and thus to colour discriminability suboptimally positioned [35], without a compensatory shortwave shift in the SWS2 pigment. The latter should prove a relatively gradual process, requiring the additive effect of at least five spectral tuning aa substitutions in its opsin [64] compared to a single nucleotide substitution in the SWS1 [5,10,11]. Conversely, a prerequisite of compensatory longwave shifts in SWS2 may explain why the SWS1 in some clades is invariably UVS, i.e. in Charadriiformes [49], in Passeriformes [51] and Psittaciformes (e.g. [52,53]).

Multifocal optics may form another constraint to substantial but isolated shifts in single cone $\lambda_{\max }$. Examining 45 species from 12 orders, Lind et al. [65] has demonstrated that birds, with few exceptions, have multifocal lenses. These consist of concentric zones with different refractive powers, which serve to reduce longitudinal chromatic aberration by selectively focusing multiple narrow wavelength bands onto the retina. As in the African cichlid Astatotilapia burtoni, where multifocal lenses were first described, these bands may closely correspond to the respective $\lambda_{\max }$ of the single cone classes present in the retina [66]. An isolated and sizeable shift in $\lambda_{\max }$ of any single cone class that is not optically corrected for should in such an eye produce a mismatch with the refractive index of the dedicated zone in the lens. The result would be chromatic blur and deteriorated spatial resolution due to an inability to simultaneously focus white light onto all single cone classes. Because longitudinal chromatic aberration increases towards the shortwave end of the spectrum (see [66]) this effect would apply to the SWS1, ultraviolet/violet sensitive, cone class in particular.

\section{Conclusions}

It is clear that avian colour vision systems are not as conserved as previously believed. To infer spectral sensitivity of a bird from a closely related species, in which the information is available, is probably still a tenable approach in large, comparative, cross-species studies. However, when the focus is one or a few particular species, it is advisable to acquire at least the most variable vision physiological data, i.e. VS or UVS colour vision system affiliation. It is 
particularly important when the study species are closely related to clades of taxa with identified shifts in the colour vision system, such as Laridae charadriiforms [49] and non-Passerida/non-Petroicidae passerines [50,51].

As ultraviolet and violet vision are important to mate choice, foraging and predator avoidance [18-34], spectral tuning of the SWS1 cone opsin presents a very rare insight into the molecular processes of ecological adaptation. We may get a clearer view of the evolution of colour vision with additional data on SWS2 sensitivities and on ocular transmission, as well as refractive indices in compound lenses. That could help to explain how shortwave colour vision has evolved, determining whether major shifts in the spectral sensitivity of the SWS1 pigment are facilitated and/or constrained by shifts in co-adapted physiological traits. Beyond the realms of eye physiology and molecular biology, deeper investigations in ecology (such as $[37,38,47,67]$ are needed to understand its role in shifting VS to UVS.

\section{Methods}

We extracted genomic DNA from quill bases of feathers, blood, muscle and other tissue material either with a GeneMole ${ }^{\circledR}$ automated nucleic acid extraction instrument (Mole Genetics), the DNeasy Blood and Tissue Kit (QIAGEN) or with Chelex. Standard procedures were applied except for the quill bases, which were lysated with $1 \%$ DTT. Feather material was sampled from a European green woodpecker Picus viridis killed by traffic. Live animals were not sampled for this study. Other tissue material was borrowed from museum collections and from the collections of colleagues, the National Veterinary Institute SVA in Uppsala and Uppsala City Council. We performed mtDNA barcoding with COI, following the Stockholm protocol outlined in [68], to confirm labelling of selected tissue samples and to identify species Ramphastos tucanus from an unspecified toucan tissue sample.

Using the degenerate primers SU80a [69], SU149a, SU161a, SU193a [42] or SU200Ca, combined with SU304b [15] or SU306b [42] we amplified a gene fragment coding for residues from aa sites 81-94, located in the 2nd $\alpha$-helical transmembrane region of the SWS1 opsin. We conducted PCR on an Eppendorf MasterCycler Gradient or a PE Applied Biosystems Geneamp ${ }^{\circledR}$ PCR System 9700 with reactions containing 0.5-2.5 ng/ $\mu \mathrm{l}$ DNA extracts, 1 unit Taq-polymerase (Applied Biosystems) plus reaction buffer, $0.4 \mathrm{pmol}$ of forward and reverse primers, $0.2 \mathrm{mM}$ of each dNTP, and $2 \mathrm{mM} \mathrm{MgCl}$. Each PCR reaction contained $0.5-2.5 n \mathrm{~g} / \mu \mathrm{l}$ total DNA extracts, 1 unit Taq-polymerase (Applied Biosystems) with reaction buffer, $0.4 \mathrm{pmol}$ of forward and reverse primers, $0.2 \mathrm{mM}$ of each dNTP, and 2 $m \mathrm{M} \mathrm{MgCl}_{2}$. For some reactions, PuReTaq ${ }^{\mathrm{TM}}$ Ready-To-Go ${ }^{\mathrm{TM}}$ PCR beads (GE Healthcare) replaced separate volumes of Taq-polymerase, dNTP's and $\mathrm{MgCl}_{2}$. Initially, the reaction conditions followed [42] (i.e. $90 \mathrm{~s}$ at $94^{\circ} \mathrm{C}, 5 \times\left(30 \mathrm{~s}\right.$ at $94^{\circ} \mathrm{C}$,
$30 \mathrm{~s}$ at $54^{\circ} \mathrm{C}$ and $1 \mathrm{~s}$ at $\left.72^{\circ} \mathrm{C}\right), 38 \times\left(15 \mathrm{~s}\right.$ at $94^{\circ} \mathrm{C}, 30 \mathrm{~s}$ at $54^{\circ} \mathrm{C}$ and $5 \mathrm{~s}$ at $72^{\circ} \mathrm{C}$ ) and $10 \mathrm{~min}$ at $72^{\circ} \mathrm{C}$ ) but were later optimized to exclude the extension phase in order to minimize nonspecific amplification of longer fragments. The final version of thermocycling started with $90 \mathrm{~s}$ at $94^{\circ} \mathrm{C}$, was followed by $48 \times\left(5 \mathrm{~s}\right.$ at $94^{\circ} \mathrm{C}, 15 \mathrm{~s}$ at $\left.54^{\circ} \mathrm{C}\right)$ and ended with $1 \mathrm{~s}$ at $72^{\circ} \mathrm{C}$. We used a different protocol for the primer pair SU80a/SU306b, namely 2 min $30 \mathrm{~s}$ at $95^{\circ} \mathrm{C}, 40 \times$ $\left(30 \mathrm{~s}\right.$ at $95^{\circ} \mathrm{C}, 30 \mathrm{~s}$ at $54^{\circ} \mathrm{C}$ and $10 \mathrm{~s}$ at $72^{\circ} \mathrm{C}$ ) and $1 \mathrm{~min}$ at $72^{\circ} \mathrm{C}$. Two percent agarose gel electrophoresis for $90 \mathrm{~min}$ at $80 \mathrm{~V}$ confirmed amplification and expected fragment length. When there were extra fragments present we sometimes performed a second PCR on the products using internal primers.

The PCR products were purified with EXOsap-IT (USB). Macrogen Inc. (South Korea) then performed double-stranded sequencing using the same primers as above plus SU200a [15], SU200Ga [60], and SU296b 5'AAG AYR AAG TAD CCS YGS G-3', which we designed for this study with the help of Primer3 online software (http://frodo.wi.mit.edu/) [70].

We translated our DNA sequences into aa's to identify the spectral tuning sites 86,90 , and 93 [5,10]. From the aa residues presents at these sites we estimated $\lambda_{\max }$ values following Wilkie et al. [5], Yokoyama et al. [10] and Carvalho et al. [11] as outlined in [15].

\section{Additional file}

Additional file 1: Table with type of SWS1 single cones (VS or UVS) interpreted from avian opsin amino acid (aa) sequences. Bold letters mark spectral tuning amino acid positions 86, 90 and 93. Amino acid residues without a known spectral tuning effect are noted. Number of birds sequenced is indicated after species names. *See note below table.

\section{Abbreviations}

$\lambda_{\text {max }}$ : Wavelength of maximum absorption; SWS1: Short wavelength sensitive type one; SWS2: Short wavelength sensitive type 2; MWS: Medium wavelength sensitive; LWS: Long-wavelength sensitive; UVS: Ultraviolet sensitive; VS: Violet sensitive; MSP: Microspectrophotometry.

\section{Competing interest}

The authors declare that they have no competing interests.

\section{Authors' contributions}

$\mathrm{AO}$ and $\mathrm{OH}$ conceived of the study. AÖ compiled the tissue material, carried out the molecular analyses, interpreted the opsin results and drafted the manuscript together with $\mathrm{OH}$. Both authors finalised and approved the manuscript.

\section{Acknowledgements}

Tissue samples were contributed by The Australian Museum, Sydney, Nicklas Backström, Sofia Berlin and Robert den Tex at the Department of Evolutionary Biology, Uppsala university, The Biology Education Centre, Uppsala university, The Department of Animal Ecology, Uppsala University, Djurkliniken Roslagstull, Stockholm, Field Museum of Natural History, Chicago, Fyris Zoo, Uppsala, Jacob Höglund, Lisa Shorey and Tobias Sahlman from The Department of Population Biology, Uppsala University, Louisiana State University Museum of Natural Science, Baton Rouge, the Swedish Museum of Natural History, Stockholm, The National Veterinary Institute of Sweden, University of Washington Burke Museum, Seattle and Uppsala 
kommun. Gunilla Engström and Jacob Höglund were helpful with technical assistance and advice. This work was funded by the Swedish Research Council Formas, the Royal Swedish Academy of Sciences, Stiftelsen för zoologisk forskning and Carl Tryggers Stiftelse för Vetenskaplig Forskning. Anonymous comments and discussions with David Hunt improved earlier versions of the manuscript.

\section{Author details}

${ }^{1}$ Department of Animal Ecology, Uppsala University, Norbyvägen 18D Uppsala S-752 36, Sweden. ${ }^{2}$ Department of Anatomy, Physiology and Biochemistry, Swedish University of Agricultural Sciences, P.O. Box 7011, Uppsala S-750 07, Sweden.

Received: 29 March 2012 Accepted: 26 October 2012

Published: 11 February 2013

\section{References}

1. Ma J-X, Kono M, Xu L, Das J, Ryan JC, Hazard ES, Oprian DD, Crouch RK: Salamander UV cone pigment: Sequence, expression, and spectral properties. Vis Neurosci 2001, 18:393-399.

2. Whitmore AV, Bowmaker JK: Seasonal variation in cone sensitivity and short-wave absorbing visual pigments in the rudd Scadinius erythrophythalmus. J Comp Physiol A 1989, 166:103-115.

3. Harosi Fl: Analysis of two spectral properties of vertebrate visual pigments. Vision Res 1994, 34:1359-1367.

4. Bowmaker JK, Knowles A: The visual pigments and oil droplets of the chicken retina. Vision Res 1977, 17:755-764.

5. Wilkie SE, Robinson PR, Cronin TW, Poopalasundaram S, Bowmaker JK, Hunt DM: Spectral tuning of avian violet- and ultraviolet-sensitive visual pigments. Biochemistry 2000, 39:7895-7901.

6. Yokoyama S: Molecular evolution of color vision in vertebrates. Gene 2002, 300:69-78.

7. Goldsmith TM, Collins JS, Licht S: The cone oil droplets of avian retinas. Vision Res 1984, 24:1661-1671.

8. Bowmaker JK, Heath LA, Wilkie SE, Hunt DM: Visual pigments and oil droplets from six classes of photoreceptor in the retinas of birds. Vision Res 1997, 37:2183-2194.

9. Hart NS, Partridge JC, Cuthill IC, Bennett ATD: Visual pigments, oil droplets, ocular media and cone photoreceptor distribution in two species of passerine bird: the blue tit (Parus caeruleus L.) and the blackbird (Turdus merula L.). J Comp Physiol A 2000, 186:375-387.

10. Yokoyama S, Radlwimmer FB, Blow NS: Ultraviolet pigments in birds evolved from violet pigments by a single amino acid change. Proc Natl Acad Sci USA 2000, 97:7366-7371

11. Carvalho LS, Cowing JA, Wilkie SE, Bowmaker JK, Hunt DM: The molecular evolution of avian ultraviolet- and violet-sensitive visual pigments. Mol Biol Evol 2007, 24:1843-1852.

12. Renoult JP, Courtiol A, Kjellberg F: When assumptions on visual system evolution matter, nestling colouration and parental visual performance in birds. J Evol Biol 2010, 23:220-225.

13. Cuthill IC, Partridge JC, Bennett ATD, Church SC, Hart NS, Hunt S: Ultraviolet vision in birds. Adv Stud Behav 2000, 29:159-214.

14. Hart NS, Hunt DM: Avian visual pigments: characteristics, spectral tuning and evolution. Am Nat 2007, 169:S7-S26.

15. Ödeen A, Hart NS, Håstad O: Assessing the use of genomic DNA as a predictor of the maximum absorbance wavelength of avian SWS1 opsin visual pigments. J Comp Physiol A 2009, 195:167-173.

16. Håstad O, Partridge JC, Ödeen A: Ultraviolet photopigment sensitivity and ocular media transmittance in gulls, with an evolutionary perspective. J Comp Physiol A 2009, 195:585-590.

17. Lind $O$, Kelber A: Avian colour vision: Effects of variation in receptor sensitivity and noise data on model predictions as compared to behavioural results. Vision Res 2009, 49:1939-1947

18. Maier EJ: To deal with "invisible": on the biological importance of ultraviolet sensitivity in birds. Naturwissenschaften 1993, 80:476-478.

19. Bennett ATD, Cuthill IC, Partridge JC, Maier EJ: Ultraviolet vision and mate choice in zebra finches. Nature 1996, 380:433-435.

20. Bennett ATD, Cuthill IC, Partridge JC, Lunau K: Ultraviolet plumage colors predict mate preferences in starlings. Proc Natl Acad Sci USA 1997, 94:8618-8621.

21. Andersson $S$, Amundsen T: Ultraviolet colour vision and ornamentation in bluethroats. Proc R SoC B 1997, 264:1587-1591.
22. Hunt S, Cuthill IC, Swaddle JP, Bennett ATD: Ultraviolet vision and band colour preferences in female zebra finches, Taeniopygia guttata. Anim Beha 1997, 54:1382-1392.

23. Hunt $\mathrm{S}$, Bennett ATD, Cuthill IC, Griffiths R: Blue tits are ultraviolet tits. ProC $R$ Soc B 1998, 265:451-455.

24. Hunt S, Cuthill IC, Bennett ATD, Griffiths R: Preferences for ultraviolet partners in the blue tit. Anim Behav 1999, 58:809-815.

25. Johnsen A, Andersson S, Ornborg J, Lifjeld JT: Ultraviolet plumage ornamentation affects social mate choice and sperm competition in bluethroats (Aves: Luscinia s. svecica): a field experiment. Proc $R$ SOC $B$ 1998, 265:313-1318.

26. Andersson S, Örnborg J, Andersson M: Ultraviolet sexual dimorphism and assortative mating in blue tits. Proc R Soc B 1998, 265:445-450.

27. Siitari $\mathrm{H}$, Honkavaara J, Huhta E, Viitala J: Ultraviolet reflection and female mate choice in the pied flycatcher, Ficedula hypoleuca. Anim Behav 2002, 63:97-102.

28. Zampiga E, Gaibani G, Csermely D: Ultraviolet reflectance and female mating preferences in the common kestrel (Falco tinnunculus). Can J Zool 2008, 86:479-483.

29. Burkhardt D: Birds, berries and UV: A note on some consequences of UV vision in birds. Naturwissenschaften 1982, 69:153-157.

30. Viitala J, Korpimäki E, Palokangas P, Koivula M: Attraction of kestrels to vole scent marks visible in ultraviolet light. Nature 1995, 373:425-427.

31. Church SC, Bennett ATD, Cuthill IC, Partridge JC: Ultraviolet cues affect the foraging behaviour of blue tits. Proc R Soc Lond B 1998, 265:1509-1514

32. Koivula M, Viitala J: Rough-legged buzzards use vole scent marks to assess hunting areas. Avian Biol 1999, 30:329-330.

33. Siitari $\mathrm{H}$, Honkavaara J, Viitala J: Ultraviolet reflection of berries attracts foraging birds. A laboratory study with redwings (Turdus iliacus) and bilberries (Vaccinium myrtilus). Proc R Soc Lond B 1999, 266:2125-2129.

34. Probst $R$, Pablicev $M$, Viitala J: UV reflecting vole scent marks attract a passerine, the great grey shrike Lanius excubitor. J Avian Biol 2002, 33:437-440.

35. Chittka L: Optimal sets of color receptors and color opponent systems for coding of natural objects in insect vision. J Theor Biol 1996, 181:179-196.

36. Vorobyev M, Osorio D: Receptor noise as a determinant of colour thresholds. Proc R Soc Lond B 1998, 265:351-358.

37. Avilés JM, Soler JJ: Nestling colouration is adjusted to parent visual performance in altricial birds. J Evol Biol 2009, 22:376-386.

38. Håstad $\mathrm{O}$, Victorsson J, Ödeen A: Differences in color vision make passerines less conspicuous in the eyes of their predators. Proc Natl Acad Sci USA 2005, 102:6391-6394.

39. Hart NS: Vision in the peafowl (Aves: Pavo cristatus). J Exp Biol 2002, 205:3925-3935.

40. Wilkie SE, Vissers PMAM, Das D, DeGrip WJ, Bowmaker JK, Hunt D: The molecular basis for UV vision in birds: spectral characteristics, CDNA sequence and retinal localization of the UV-sensitive visual pigment of the budgerigar (Melopsittacus undulatus). Biochem J 1998, 330:541-547.

41. Nathans J, Hogness DS: Isolation, sequence analysis, and intron-exon arrangement of the gene encoding bovine rhodopsin. Cell 1983, 34:807-814.

42. Ödeen A, Håstad O: Complex distribution of avian color vision systems revealed by sequencing the SWS1 opsin from total DNA. Mol Biol Evol 2003, 20:855-861.

43. Gill F, Donsker D (Eds): IOC World Bird Names (version 2.9). 2011. Available at http://www.worldbirdnames.org/ [Accessed Aug. 23 2011].

44. Hackett SJ, Kimball RT, Reddy S, Bowie RCK, Braun EL, Braun MJ, Chojnowski JL, Cox WA, Han K-L, Harshman J, Huddleston CJ, Marks BD, Miglia KJ, Moore WS, Sheldon FH, Steadman DW, Witt CC, Yuri T: A phylogenomic study of birds reveals their evolutionary history. Science 2008, 320:1763-1768.

45. Machovsky Capuska GE, Huynen L, Lambert D, Raubenheimer D: UVS is rare in seabirds. Vision Res 2011, 51:1333-1337.

46. Ismar SMH, Chong NL, Igic B, Baird K, Ortiz-Catedral L, Fidler AE, Hauber ME: Visual sensitivity, coloration and morphology of red-tailed tropicbirds Phaethon rubricauda breeding on the Kermadec Islands. New Zealand J Zool 2011, 38:29-42.

47. Håstad $O$, Ernstdotter E, Ödeen A: Ultraviolet vision and foraging in dip and plunge diving birds. Biol Lett 2005, 1:306-309.

48. Wright M, Bowmaker JK: Retinal photoreceptors of paleognathous birds: the ostrich (Strutio camelus) and rhea (Rhea americana). Vision Res 2001, 41:1-2. 
49. Ödeen $A$, Håstad O, Alström P: Evolution of ultraviolet vision in shorebirds (Charadriiformes). Biol Lett 2010, 6:370-374.

50. Ödeen A, Pruett-Jones S, Driskell AC, Armenta JK, Håstad O: Multiple shifts between violet and ultraviolet vision in a family of passerine birds with associated changes in plumage coloration. Proc R Soc B 2012, 279:1269-1276.

51. Ödeen A, Håstad O, Alström P: Evolution of ultraviolet vision in the largest avian radiation - the passerines. BMC Evol Biol 2011, 11:313.

52. Aidala Z, Huynen L, Brennan PLR, Musser J, Fidler A, Chong N, Machovsky Capuska GE, Anderson MG, Talaba A, Lambert D, Hauber ME: Ultraviolet visual sensitivity in three avian lineages: paleognaths, parrots, and passerines. J Comp Physiol A 2012, 198:495-510.

53. Carvalho LS, Knott B, Berg ML, Bennett ATD, Hunt DM: Ultraviolet-sensitive vision in long-lived birds. Proc $R$ Soc B 2011, 278:107-114.

54. Okano T, Kojima D, Fukada Y, Shichida Y, Yoshizawa T: Primary structures of chicken cone visual pigments: Vertebrate rhodopsins have evolved out of cone visual pigments. Proc Natl Acad Sci USA 1992, 89:5932-5936.

55. Das D, Wilkie SE, Hunt DM, Bowmaker JK: Visual pigments and oil droplets in the retina of a passerine bird, the canary Serinus canaria: microspectrophotometry and opsin sequences. Vision Res 1999, 39:2801-2815.

56. Kawamura S, Blow NS, Yokoyama S: Genetic analyses of visual pigments of the Pigeon (Columba livia). Genetics 1999, 153:1839-1850.

57. Wright SG, Dearborn DC: Male ornament variation in a sexually dimorphic seabird with variable male mating success. Evol Ecol Res 2009, 11:759-770.

58. Ödeen A, Håstad O: Pollinating birds differ in spectral sensitivity. J Comp Physiol A 2010, 196:91-96.

59. Carvalho LS, Davies WL, Robinson PR, Hunt DM: Spectral tuning and evolution of primate short-wavelength-sensitive visual pigments. Proc $R$ Soc B 2012, 279:387-393.

60. Seddon N, Tobias JA, Eaton M, Ödeen A: Human vision can provide a valid proxy for avian perception of sexual dichromatism. Auk 2010, 127:283-292.

61. Johansson US, Fjeldså J, Bowie RCK: Phylogenetic relationships within Passerida (Aves: Passeriformes): A review and a new molecular phylogeny based on three nuclear intron markers. Mol Phylogenet Evol 2008, 48:858-876.

62. Boulton M, Rózanowska M, Rózanowski B: Retinal photodamage. J Photochem Photobiol 2001, 64:144-161.

63. Lythgoe JN: The ecology of vision. Oxford: Oxford University Press; 1979

64. Yokoyama S, Tada T: The spectral tuning in the short wavelengthsensitive type 2 pigments. Gene 2003, 306:91-98.

65. Lind OE, Kelber A, Kröger RHH: Multifocal optical systems and pupil dynamics in birds. J Exp Biol 2008, 211:2752-2758.

66. Kröger RHH, Campbell MCW, Fernald RD, Wagner H-J: Multifocal lenses compensate for chromatic defocus in vertebrate eyes. $J$ Comp Physiol $A$ 1999, 184:361-369.

67. Mullen P, Pohland G: Studies on UV reflection in feathers of some 1000 bird species: are UV peaks in feathers correlated with violet-sensitive and ultraviolet-sensitive cones? Ibis 2008, 150:59-68,

68. Johnsen A, Rindal E, Ericson PGP, Zuccon D, Kerr KCR, Stoeckle MY, Lifjeld JT: DNA barcoding of Scandinavian birds reveals divergent lineages in trans-Atlantic species. J Ornithol 2010, 151:565-578.

69. Ödeen A, Håstad O: New primers for the avian SWS1 pigment opsin gene reveal new amino acid configurations in spectral sensitivity tuning sites. J Hered 2009, 100:784-789.

70. Rozen S, Skaletsky HJ: Primer3 on the WWW for general users and for biologist programmers. In Bioinformatics Methods and Protocols: Methods in Molecular Biology. Edited by Krawetz S, Misener S. Totowa, NJ: Humana Press; 2000:365-386.

doi:10.1186/1471-2148-13-36

Cite this article as: Ödeen and Håstad: The phylogenetic distribution of ultraviolet sensitivity in birds. BMC Evolutionary Biology 2013 13:36.

\section{Submit your next manuscript to BioMed Central and take full advantage of:}

- Convenient online submission

- Thorough peer review

- No space constraints or color figure charges

- Immediate publication on acceptance

- Inclusion in PubMed, CAS, Scopus and Google Scholar

- Research which is freely available for redistribution

Submit your manuscript at www.biomedcentral.com/submit
Ciomed Central 